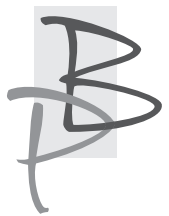

Jarosław Ławski*

Katedra Badań Filologicznych „Wschód - Zachód”, Uniwersytet w Białymstoku https://orcid.org/0000-0002-1167-5041

\title{
Międzynarodowa Konferencja Naukowa „Polonistyki w Europie Środkowo-Wschodniej - teraźniejszość i perspektywy rozwoju", Warszawa, 20-21 listopada 2018 r. Sprawozdanie
}

Polonistyka jest tą dziedziną badań filologicznych, która szczególne znaczenie ma w krajach powstałych na dawnych ziemiach Rzeczypospolitej: Litwie, Białorusi i Ukrainie. W każdym z tych niepodległych państw jej losy toczą się nieco innym torem: na Ukrainie język polski jest w tej chwili najpopularniejszym językiem obcym nauczanym w tym kraju, co przy dość szczupłej kadrze filologów polskich niekoniecznie dobrze wpływa na podnoszenie poziomu studiów polonistycznych i takichże badań ${ }^{1}$. Na Białorusi można chyba mówić o dłuższym kryzysie polonistyki (zlikwidowano studia polonistycznie w Grodnie), brak tu kadr, silny jest kontekst polityczny. Litwa z kolei ma aż dwa ośrodki polonistyczne w Wilnie (Uniwersytet Wileński oraz Litewski Uniwersytet Edukologiczny połączony w 2018 roku z Uniwersytetem Witolda Wielkiego w Kownie), których nie dało się do tej pory ani zintegrować, ani rozwinać w jakiejś innej formule.

\footnotetext{
Jarosław Ławski - prof. dr hab., kierownik Katedry Badań Filologicznych „Wschód - Zachód" na Wydziale Filologicznym Uniwersytetu w Białymstoku. Autor m.in. monografii Mickiewicz - Mit - Historia. Studia (Białystok 2010); Miłosz: „Kroniki” istnienia. Sylwy (Białystok 2014). Edytor Horsztyńskiego J. Słowackiego w serii Biblioteki Narodowej oraz III-tomowych Pism rozproszonych Zygmunta Glogera. Członek Komitetu Nauk o Literaturze PAN; członek korespondent Polskiej Akademii Umiejętności.

1 To znaczy: przybywa uczących się języka polskiego, lecz nie przybywa wykwalifikowanej kadry.
} 
Sytuację kształtują też zawirowania polityczne w tej części Europy. Nie bez znaczenia pozostają mniejszości: polska w tych krajach i litewska, białoruska, ukraińska w Polsce.

W tej sytuacji konieczne wprost wydaje się ze strony państwa polskiego wspomaganie polonistyki w tych państwach, koordynowanie wsparcia, monitorowanie sytuacji i umożliwianie filologom wymiany doświadczeń.

Tym celom służyła zorganizowana w Warszawie, w Sali im. A. Mickiewicza w Instytucie Badań Literackich PAN Międzynarodowa Konferencja Naukowa „Polonistyki w Europie Środkowo-Wschodniej - teraźniejszość i perspektywy rozwoju" (20-21 listopada 2018 r.).

Zorganizowała ją wspólnie grupa polskich podmiotów, zainteresowanych współpracą ze Wschodem: Komitet Nauk o Literaturze PAN, IBL PAN, Międzynarodowe Stowarzyszenie Studiów Polonistycznych, Wydział Filologiczny Uniwersytetu w Białymstoku, Wydział Filologiczny Uniwersytetu Wrocławskiego oraz Wydział Nauk Humanistycznych UKSW. Instytucje te wspólnie opłaciły koszty podróży badaczy ze Wschodu do Polski, ich pobytu i udziału w sesji. Trud koordynacji prac nad przygotowaniem sesji spadł na prof. Tomasza Chachulskiego (UKSW, Warszawa) i prof. Magdalenę Popiel (MSSP, Kraków). Z zadania tego, co należy podkreślić, wywiązali się znakomicie.

Do Warszawy przyjechało ok. 40 badaczy ze Wschodu (4 z Litwy, 4 z Białorusi, 16 z Ukrainy) oraz 16 polskich naukowców specjalizujących się w tematyce wschodniej. Reprezentowane były takie ośrodki, jak Kijów, Mińsk, Grodno, Wilno, Odessa, Lwów, Iwano-Frankiwsk, Czerniowce.

Sesję otworzyły przemówienia powitalne prof. Mikołaja Sokołowskiego (IBL PAN), prof. Magdaleny Popiel, która zaprezentowała Projekt „Geopolonistyka", realizowany przez MSSP, oraz prof. Tomasza Czachulskiego (KNoL PAN). Spotkanie pomyślano zarówno jako konferencję z cyklem referatów, jak i spotkanie warsztatowe, podczas którego goście z Europu Wschodniej mogli zapoznać się z ofertą polskiego wsparcia ich działań (część wystąpień przygotowanych na tę okazję była jednak zbyt ogólna i niewiele, co trzeba przyznać samokrytycznie, miała wspólnego z realiami nauki wschodnioeuropejskiej). Do najciekawszych zaliczyć można wystąpienia: Jolanty Tambor (UŚ, MSSP) $P u$ blikacje po IV Światowym Kongresie Polonistów, Marioli Wilczak (IBL PAN) „Biuletyn Polonistyczny” - krajowy i międzynarodowy portal środowiskowy, 
Marcina Cieńskiego i Anny Dąbrowskiej (UWr) Przed VIII Światowym Kongresem Polonistów Wrocław 2020.

Za nieporozumienie uznalibyśmy ogólnikową prezentację Łukasza Wojdygi i Kamili Dembińskiej Propozycje NAWA dla środowisk Europy Środkowo-Wschodniej.

Trudno bodaj w skrócie oddać bogactwo wystąpień polonistów z Ukrainy (najliczniej reprezentowanych), Litwy i Białorusi. Część wystąpień miała charakter prezentacji „osiągnięć”, część podejmowała realne problemy, choć $\mathrm{z}$ różnych powodów - trudno było w takim gronie o swobodną dyskusję przedstawicieli czterech tak zupełnie różnych środowisk naukowych, funkcjonujących w bardzo odmiennych kontekstach społeczno-politycznych.

Wymieńmy wybrane prezentacje i referaty:

Białoruś:

- Białoruski Uniwersytet Państwowy w Mińsku:

Mikołaj Chmialnicki, Polonistyka na Uniwersytecie Państwowym w Mińsku: osiagnięcia i problemy;

- Narodowa Akademia Nauk Białorusi, Instytut Literaturoznawstwa im. Janki Kupały:

Alaxandr Brazgunou, Badania nad literatura polska w Akademii Nauk Białorusi: 1991-2017;

- Państwowy Uniwersytet Grodzieński im. Janki Kupały:

Swietłana Musijenko, Los polonistyki na Uniwersytecie Grodzieńskim. Muzeum Zofii Nałkowskiej jako naukowo-dydaktyczna jednostka kultury polskiej na Białorusi;

Helena Nielepko, Wycieczki w Muzeum Zofii Nałkowskiej. Osobliwości wykładania języka polskiego na Uniwersytecie Grodzieńskim;

Litwa:

- Uniwersytet Wileński, Wydział Filologiczny, Instytut Języków i Kultur Regionu Bałtyckiego, Centrum Polonistyczne:

Mirosław Dawlewicz, Polonistyka na Uniwersytecie Wileńskim - tradycje i teraźniejszość;

Regina Jakubėnas, Specyfika programu studiów polonistycznych na Uniwersytecie Wileńskim;

- Uniwersytet Witolda Wielkiego, Akademia Edukacji, Instytut Kształcenia Nauczycieli: 
Irena Masojć, Dorobek naukowy polonistów z Litewskiego Uniwersytetu Edukologicznego a nowe wyzwania badawcze;

Henryka Sokołowska, Studia polonistyczne o ukierunkowaniu pedagogicznym w Wilnie. Wspótczesne uwarunkowania na tle wieloletnich tradycji;

Ukraina:

- Narodowy Uniwersytet im. Tarasa Szewczenki w Kijowie:

Rościsław Radyszewski, Katedra Polonistyki w Kijowie i jej działalność;

Marija Bracka, Proces dydaktyczno-naukowy na polonistyce kijowskiej: stan obecny i perspektywy;

- Narodowy Uniwersytet „Akademia Kijowsko-Mohylańska”:

Lidia Nepop-Ajdaczyć, Nauki polonistyczne na Narodowym Uniwersytecie „Akademia Kijowsko-Mohylańska”: obecny stan i perspektywy rozwojowe.

Wśród referentów znaleźli się także: dr hab. Paweł Bukowiec (UJ), prof. Elena Wojcewa (Odessa), dr Olga Ciwkacz (Iwano-Frankiwsk), Jerzy Kowalewski (Fundacja Wolność i Demokracja).

Środowisko białostockie reprezentowali prof. Anna Kieżuń i prof. Jarosław Ławski, który pierwszego dnia spotkania przedstawił referat Perspektywy wspótpracy filologów z Polski i Europy Środkowo-Wschodniej w świetle przeprowadzanych „reform” nauki. Nieodłączną częścią spotkania były wspólne posiłki i kuluarowe spotkania w Hotelu „Logos”.

Nie można mieć wątpliwości, iż tego typu konferencje powinny zyskać charakter cykliczny i obejmować stale większą lub inną (według zróżnicowania geograficzno-kulturowego) liczbę polonistycznych środowisk nie tylko z Europy, lecz i świata. Trzeba, by spotkania takie odbywały się pod wyraźnym patronatem władz polskich (MNiSW, MSZ, MKiDN, PAN), z udziałem wszystkich polskich uniwersytetów. Powinniśmy zadbać, żeby ich finansowanie nie było problemem ${ }^{2}$. Zmusza do takiej aktywności nie tylko to, co się dzieje za wschodnią granicą Rzeczypospolitej, lecz również dobrze rozumiany interes państwa i jego kultury. 